\title{
Commercial and household food waste separation behaviour and the role of Local Authority: a case study
}

\author{
Mamun Jamal $^{1,2} \oplus \cdot$ Aleksandra Szefler $^{2} \cdot$ Colman Kelly $^{2,3} \cdot$ Nicholas Bond $^{2,3}$
}

Received: 7 October 2018 / Accepted: 18 September 2019 / Published online: 30 September 2019

(c) The Author(s) 2019

\begin{abstract}
Purpose Source segregation of food waste is one of the major challenges that inhibit food waste recycling around the world. Therefore, the purpose of this study was to investigate the role of the local authority to implement regulations and encourage an increase in the source separation of food waste within both commercial premises and households, and identifying any gaps that exist in public awareness.

Methods This study was conducted by the Cork County Council in 568 commercial premises and 1362 houses in County Cork, Ireland. This study also included investigations of public and private civic amenity sites and waste collectors that collect kerb side waste located within the region. The interviewee's responses were documented and a database has been prepared and analysed.

Results Integrated strategy is crucial to roll out food waste bin within a community for successful implementation of source segregation of food waste. This strategy should involve a dedicated team from the local authority who continue to visit, monitor and co-ordinate the activities of local authorities, waste collectors, civic amenity sites and public to implement and enforce the food waste regulations. In addition to organising appropriate infrastructure for recycling of food waste, continuous awareness raising through education, leaflets and local and national media is also crucial.

Conclusion The role of local authorities should include facilitating the development of appropriate facilities such as composting, anaerobic digestion within communities and to encourage communities to take ownership of these facilities and reuse the resultant material within the local area.
\end{abstract}

Keywords Local Authority $\cdot$ Food waste $\cdot$ Ireland $\cdot$ Brown bin $\cdot$ County Council

Electronic supplementary material The online version of this article (https://doi.org/10.1007/s40093-019-00300-z) contains supplementary material, which is available to authorized users.

Mamun Jamal

mamun.jamal@chem.kuet.ac.bd

Nicholas Bond

nicholas.bond@corkcoco.ie

1 Department of Chemistry, Khulna University of Engineering \& Technology, Khulna 9203, Bangladesh

2 Environment Directorate, Cork County Council, Inniscarra, Cork, Ireland

3 WERLA-Southern Region, Environment Directorate, Cork County Council, Inniscarra, Cork, Ireland

\section{Introduction}

Increasing waste generation annually, along with heavy reliance on land filling as a disposal method has significant impact on landfill capacity, health and environment in Europe and around the world. Therefore, the European Union set out Legislation under the Landfill Directive (EU Directive 1999) on prohibiting the disposal of food waste to landfill. It has been identified that the process of separation of food waste at its generation source an efficient way to reduce unnecessary food purchase, as well as reduce sending the amount of food waste to landfill, ultimately lowers the greenhouse gases that generates from the landfill. Moreover, source segregated food waste can be used as feedstock to downstream treatment processes, namely composting, anaerobic digestion, hybrid LCA approach (Salemdeeb et al. 2018) and ultimately to recover energy and replenish soil. In addition to creating opportunities for added values 
and jobs, the practice of segregating food waste will demonstrate to the householders the amount of food being wasted and result in a consequent reduction. For example, in USA alone, almost 45 billion $\mathrm{kg}$ of grain products, fruits, milks and fresh vegetables is lost to waste every year. According to the Environmental Protection Agency, USA, the disposal of this costs approximately $\$ 1$ billion (Kosseva 2009). In the United Kingdom, 20 million tons of food waste is produced annually and a major portion of this waste ends up in the landfill. Every tonne of food waste equates to 4.5 tons of $\mathrm{CO}_{2}$ emissions, a greenhouse gas that has negative impact on the environment. Moreover, the estimated direct cost to producers of food that goes to waste globally is currently US $\$ 750$ billion annually, a figure that excludes even wasted fish and seafood. Therefore, every regulatory authority must take the lead through proper consultation and communication in order to get all of the stakeholders working together to achieve the target of reducing landfill waste.

A number of efficient measures have taken place in many European countries such as The Netherlands, Germany, Austria, Sweden and Spain to implement food waste regulations. Strong participation of both households and commercial premises in the primary action of source-segregation is the crucial factor that is found to be the common in all these countries. Therefore, it is important also to find out the motives of both households and commercial premises behind involvement in such schemes. Numerous articles have been published in scientific journals discussing the impact related to a multiplicity of different factors within household and commercial premises that affect the involvement rate in waste recycling schemes. Factors such as (1) demographic profile (Berglund 2006; Dietz et al. 1998; Sterner and Bartelings 1999; Vicente and Reis 2008); (2) the influence of local norms and environmental awareness (Hopper and Nielsen 1991; Widegren 1998; Sterner and Bartelings 1999); (3) implementing incentives, such as pay by weight on residual waste; (4) regular collection of food waste; appropriate facilities in the local amenity sites to recycle food waste; (5) education and awareness raising through seminars, conferences, local medias (radio, newspaper, television) (Williams and Taylor 2004; Austin et al. 2003; Spaccarelli et al. 1989) have been suggested as an effective strategy in order to increase recycling. However, a number of articles have described factors that are more important than others. Anna Bernstad (2014) has suggested that the installation of equipment and existence of infrastructure is crucial and is more important for source-segregation of waste compared to the use of written information: such as distribution of leaflets among the households. Wan Azlina et al. (2013) also suggested that good moral values and situational factors such as storage convenience and collection times encourage public involvement and increase the participation rates on source segregation of food waste. On the other hand, Evison and
Read (2001) suggested that education and quality promotion and publicity on a regular basis are essential for the success of any recycling scheme. Evison also mentioned that local newspapers are not always the best means of informing the public, rather local authority environmental newspapers are more efficient in forwarding the policies and strategies to the public. In addition, educating public on waste management and recycling is also found to be crucial and should be organised by the central government or national body rather than local authority. Moh and Manaf (2014) suggested that regulatory compliance in solid waste management, such as imposing fees or charges and mandatory household recycling could be given serious consideration for the implementation of food waste recycling within household premises. In addition to civic amenity sites, authors also suggested more recycling drop-off centres at public and convenient locations such as the family shopping malls. These should be provided with effective and efficient recycling collection services. However, source segregation of food waste is still one of the challenges in Europe and other parts of the world. In addition to that, it is also crucial to find out the motives of personnel in households and commercial premises behind such involvement and the role of local authority in overall.

Therefore, the aim of this study was to investigate the role of the local authority to implement and increase the source separation of food waste within both commercial premises and households, and identifying any gaps that exist in public awareness. A brown bin adviser pilot scheme has been implemented to conduct this study, where brown bin advisers on behalf of the local authority coordinate with food waste recycling to commercial and household premises; and build a link between local authority and waste collectors, local civic amenity sites and public, to successfully implementing recycling policy within a specific zone. In our knowledge, very little study has been done from the local authority point of view on implementing an approach towards successful campaign of food waste recycling.

\section{Methods}

The present study was conducted by the Cork County Council through brown bin adviser scheme in 568 commercial premises located within 22 towns and 1362 houses located within five major towns in County Cork with a population agglomeration $>10,000$. County Cork is the largest county (by area) located in the south-west region of Ireland, with a population of 518,128 and area of $7500 \mathrm{~km}^{2}$. This study also included investigations of public and private civic amenity sites and waste collectors that collect kerb side waste located within the region. The interviewee's responses were documented and a database has been prepared and analysed. Figure 1 explains 
the overall brown bin scheme that has been implemented by Cork County. Cork County Council recruited additional "brown Bin" advisers to supplement their own staff who co-ordinated on behalf of Council with the household and commercial premises, waste collectors, civic amenity sites, composting facilities, anaerobic digestion facilities, local medias and local schools. However, their communication was strong with waste collectors, commercial premises and civic amenity sites through phone calls, emails, letters and enforcement actions; reminding them on their obligations on a regular basis. Advice and awareness information was communicated to householders and also to the school children through the Green schools initiatives.

\section{Population and area}

In this study, all the commercial premises that produce food waste have been targeted within all the major towns in County Cork and for the households, the towns which have population agglomeration more than 10,000 (Table 1). In households, the number of samples selected from each town was $6 \%$, which is directly proportional to the size of the population in each town and also different estates in each town have been selected based on their standard of living which has been taken from the Geo data (lower, middle and upper income group ). Waste collectors have been contacted on a regular basis through phone, email and post. Local authority also organised a number of meetings, seminars with the waste collectors and awareness events with the local businesses and tidy town volunteers (in every town in Cork, there are few locals who volunteer to make the town tidy; this is organized by the local authority). Local civic
Table 1 Number of commercial premises that generate sourcesegregated food waste at various towns in County Cork

\begin{tabular}{|c|c|}
\hline Towns & $\begin{array}{l}\text { Number of } \\
\text { premises }\end{array}$ \\
\hline Ballincollig $^{\mathrm{a}}$ & 44 \\
\hline Bandon & 37 \\
\hline Bantry & 21 \\
\hline Blarney & 7 \\
\hline Boherbue & 2 \\
\hline Carrigaline $^{\mathrm{a}}$ & 24 \\
\hline Carrigtwohill & 4 \\
\hline Castletownbere & 21 \\
\hline Charleville & 15 \\
\hline Clonakilty & 37 \\
\hline Cobh $^{\mathrm{a}}$ & 40 \\
\hline Dunmanway & 14 \\
\hline Fermoy & 30 \\
\hline Kanturk & 15 \\
\hline Kinsale & 45 \\
\hline Macroom & 19 \\
\hline Mallow $^{\mathrm{a}}$ & 46 \\
\hline Midleton $^{\mathrm{a}}$ & 40 \\
\hline Millstreet & 17 \\
\hline Mitchelstown & 29 \\
\hline Skibbereen & 23 \\
\hline Youghal & 38 \\
\hline
\end{tabular}

amenity sites have been visited by the brown bin advisers and the issues involved have been documented and analysed.
Fig. 1 Flow diagram of methodology on the co-ordination of Brown Bin Adviser (inset: Brown Bins)

\section{Brown Bin Adviser: Food Waste Collection}

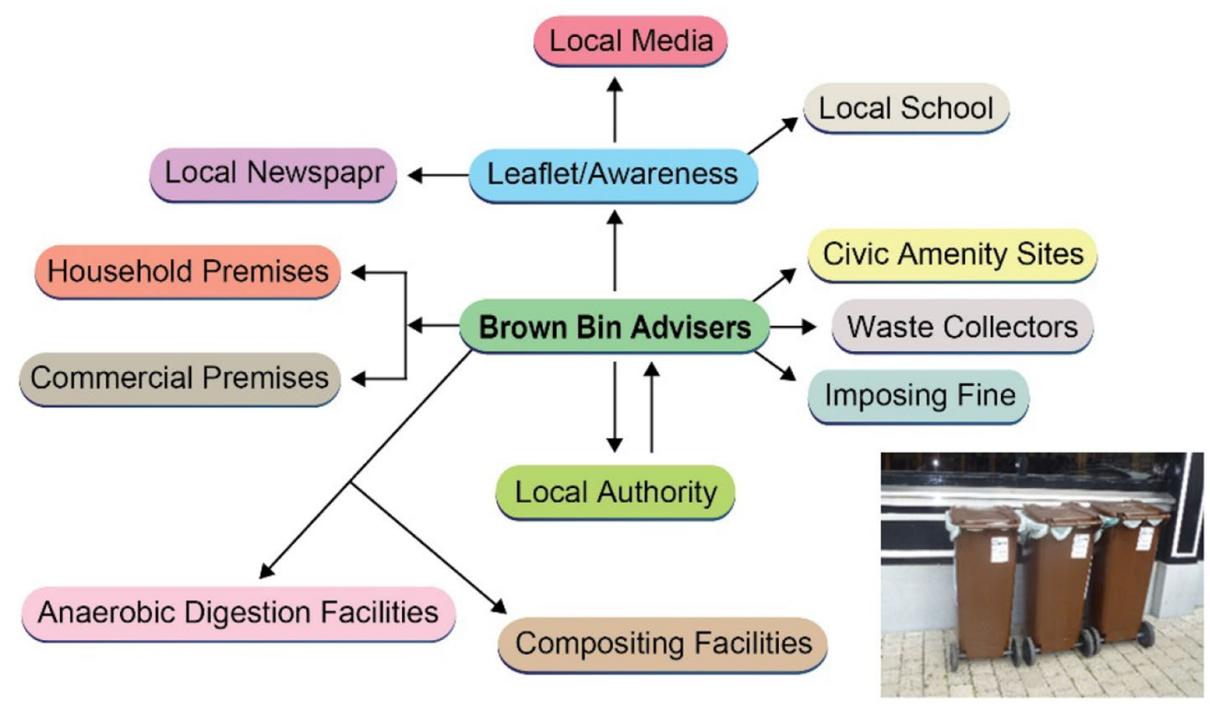




\section{Questionnaire, data collection and analysis}

To determine the demographic status and plan of the respondent for the commercial premises (Supplementary Fig. S1) and for the households (Supplementary Fig. S2) a questionnaire was designed. Questionnaire for the commercial premises contained ten points with their follow-up details. The ultimate goal of these points is to understand whether they are doing source segregation; if not, then what are the next steps. Also relevant leaflets are handed to them. In relation to households, it was more instructive as to how to use brown bin, who to contact, along with the leaflets that are provided by the brown bin advisers. Their experience and comments also have been documented and analysed. The data analysis was performed using the xl data sheets and using pivot plots. It is to confirm that the identity of any respondent in this study was not disclosed; and an assumption has been used that the respondents in this study are answering honestly. However, a cross-sectional study was used for the validation of all the data given by the respondents.

\section{Results and discussion}

\section{Respondents' demographic information (commercial premises)}

A total of 568 commercial premises in 22 towns within County Cork that produced food waste have been visited by the local authority as per this case study. After the first visit by the local authority advisers, average 53\% premises participated in the brown bin scheme (Fig. 2), which increased to average $81 \%$ after the second visit. As an observation, of the towns that are located in the remote area, the majority of the premises were found to be reluctant to engage with food waste collection service and demonstated very slow rate of compliance. On the other hand, commercial premises located in town with tourist spots show higher rate of compliance. However, inspections carried out by the Brown Bin advisers to remind commercial premises of their obligations encouraged the source segregation of food waste. Specially, hospitals, nursing homes and supermarkets are ahead in participating brown bin scheme from the beginning, as compared to the other types of commercial premises such as fast food establishments or cafes (Fig. 3, Table 2). Fast food establishments or cafes usually require more explanations, encouragement and occasionally multiple visits from local authority for participating in food waste recycle scheme. For ethnic commercial premises (such as Chinese, Indian), it was found to be very effective to issue letters; along with the

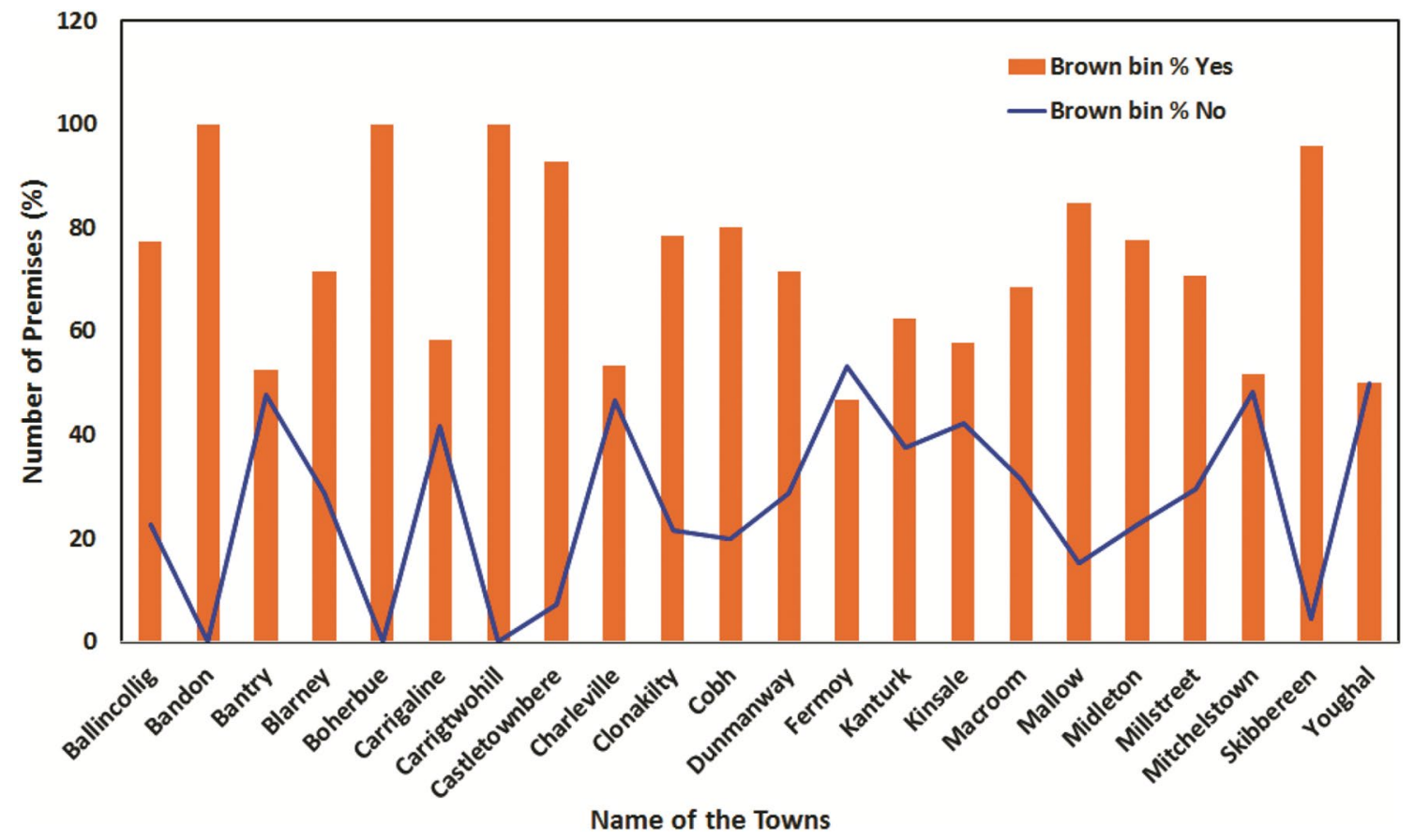

Fig. 2 Brown bin status (yes or no, \%) for the commercial premises at various towns in County after first visit 


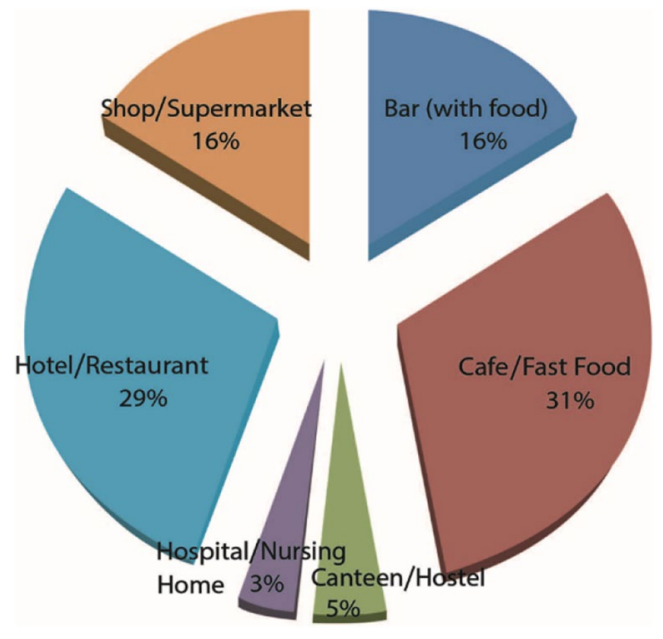

Fig. 3 Distribution (\%) of commercial premises in County Cork that generate source segregated food waste

Table 2 Types of commercial premises that are found to be compliant (\%) after the first and the second visits by the brown bin advisers

\begin{tabular}{llc}
\hline Premises type & $\begin{array}{l}\text { Compliant after 1st } \\
\text { visit (\%) }\end{array}$ & $\begin{array}{l}\text { Compliant after } \\
\text { 2nd visit (\%) }\end{array}$ \\
\hline Bar (with food) & 47 & 80 \\
Cafe/fast food & 27 & 57 \\
Canteen/hostel & 66 & 100 \\
Hospital/nursing home & 78 & 100 \\
Hotel/restaurant & 40 & 62 \\
Shop/supermarket & 54 & 89 \\
\hline
\end{tabular}

visits, as they find it clearer, easier and reliable to understand through written communications. Among the restaurants, bars, shops-in approximately $30-40 \%$ of cases food waste is being taken by the local farmers to feed animals (i.e. dogs, pigs, hounds), which used to be the usual practice until 2001 in Ireland. However, to improve the security of food chain and to sustain food industry in Ireland, a ban has been introduced on feeding food waste to animal, unless individuals or company holds meat feeding license. However, this historic practice is also found to be one of the factors in delaying taking brown bin on board for the owners in commercial premises in Ireland. In this case the presence of brown bin adviser on the door has a huge impact on accepting brown bin scheme within these premises. Also follow-up phone call after first visit is crucial to obtain maximum turnover during the second visit. Ultimately, reinforcing the importance of source segregation of food waste to the food producers will make a significant difference to the practice of food waste recovery. Also majority food producers find it more encouraging to do it once their peer business people practice it and ask neighbour or colleague to use it. Figure 3 shows types of premises that generate food waste in Cork. Cafes, fast food establishments, hotels and restaurants are found to be the major food waste producers in Cork, though rate of participation in the food waste recycling is slower within these premises compared to the other types of commercial premises, such as hospitals, bars and canteens.

\section{Respondents' demographic information (households)}

Brown bin advisers from Cork County Council have visited 1362 households located within the five largest towns in County Cork, and $29 \%$ of the households have been met by the advisers face to face. Leaflets with contact details have been dropped to the remaining $71 \%$ houses in relation to the legislation and the procedure of food waste segregation (Table 3). After arbitrary re-inspection it has been observed that approximately $50 \%$ households participated in the brown bin scheme within 6 weeks of first visit. However, the majority households responded that appropriate collection of food waste would encourage food waste segregation at home. In particular, those households that are given food waste bins at home and are being collected by the waste collector in a regular basis, and even in some cases it is collected more often that other wastes, are viewed the most encouraging by the householders to do source segregation of food waste. Even though, just the presence of the food waste bins at home also found to be effective on the involvement of source segregation food waste, which is mainly due to the neighbourhood's perceptions. However, it is also found that just providing a composter unit to every household is not that much effective in encouraging householders to do food waste separation at home. Typical questions from the households when brown bin advisers go to their door are: (1) confusion as to what to put and what not to put into the brown bin, (2) how to clean the bin/caddy, (3) concerns on lots of flies at home due to the food waste bin, (4) need a wheelie bin as it is very heavy to carry, (5) will it cost any extra? (6) Problem of space for another extra bin, etc. Therefore, appropriate training on

Table 3 Number of households inspected by the brown bin advisers in County Cork

\begin{tabular}{lllll}
\hline Towns & $\begin{array}{l}\text { No. of } \\
\text { houses } \\
\text { audited }\end{array}$ & $\begin{array}{l}\text { \% of houses } \\
\text { audited }\end{array}$ & Advising \% & $\begin{array}{l}\text { Leaflets } \\
\text { only \% }\end{array}$ \\
\hline Ballincollig & 347 & 6 & 31 & 69 \\
Carrigaline & 296 & 6 & 32 & 68 \\
Cobh & 247 & 6 & 28 & 72 \\
Mallow & 232 & 6 & 24 & 76 \\
Midleton & 240 & 6 & 28 & 72 \\
\hline
\end{tabular}


preparing brown bin advisers or personnel from the local authority is needed to ensure effective communication with the householders.

Due to the presence of food waste bin at home, people also realise how much food is being wasted in a regular basis. In addition to recycling food waste, generating less food waste is also very crucial for the success of this scheme. Food for consumption goes through different phases, and there are losses at each phase. Losses occur during production and harvest (i.e. drought) stage, postharvest, handling and storage stage, packaging and processing stage, distribution and retail stage and finally consumer stages (i.e. households, restaurants, etc). Introduction of food waste recycling scheme will have psychological impact and drive the consumers to reduce generating food waste. Moreover, consumers will buy durable and long-lasting food items, reuse the cooked food and will be forced not to buy unnecessary food. Also it promotes the practice of 'encouraging others attitude' on reducing food waste, or purchase exactly what consumers need. Due to extensive enforcement, $37 \%$ decrease in household waste disposed to landfill has been found in 2013 compared to 2012 in Ireland, and County Cork is following the same trend.

\section{Civic Amenity Sites}

Audits have been carried out on public and private recycling centres in County Cork aimed to review and evaluate both the site attendants' and customers' attitude towards food waste recycling. Locations of the recycling centres are marked in Fig. 4; however, brown bin advisers visited four centres for this survey: two in Midleton, one in Cobh and one in Mallow. After visiting and talking to people within the sites, it has been realised that site attendants have an important role in encouraging and educating customers to segregate waste more efficiently at the respective sites. Moreover, longer opening hours, better signage and layout along with publicity, education and awareness campaigns would enable the public to use the site more efficiently. UK local authority has done a huge amount of work to improve the efficiency of local amenity sites, e.g. Lancashire County Council (Williams and Taylor 2004) has changed the name of the local amenity sites to Household Waste Recycling Centres that enhanced positive image of these sites within the society. Williams et al. also suggested the provision of boxes or bin liners from the amenity sites that would facilitate pre-separation of the waste and encourage source segregation of food waste. Supplementary Table 1 details an EPA report, estimated household organic waste collected by Civic Sites in Cork. However, additional work is required and in progress to organise the Civic Sites in Cork to facilitate acceptance of source segregated food waste.

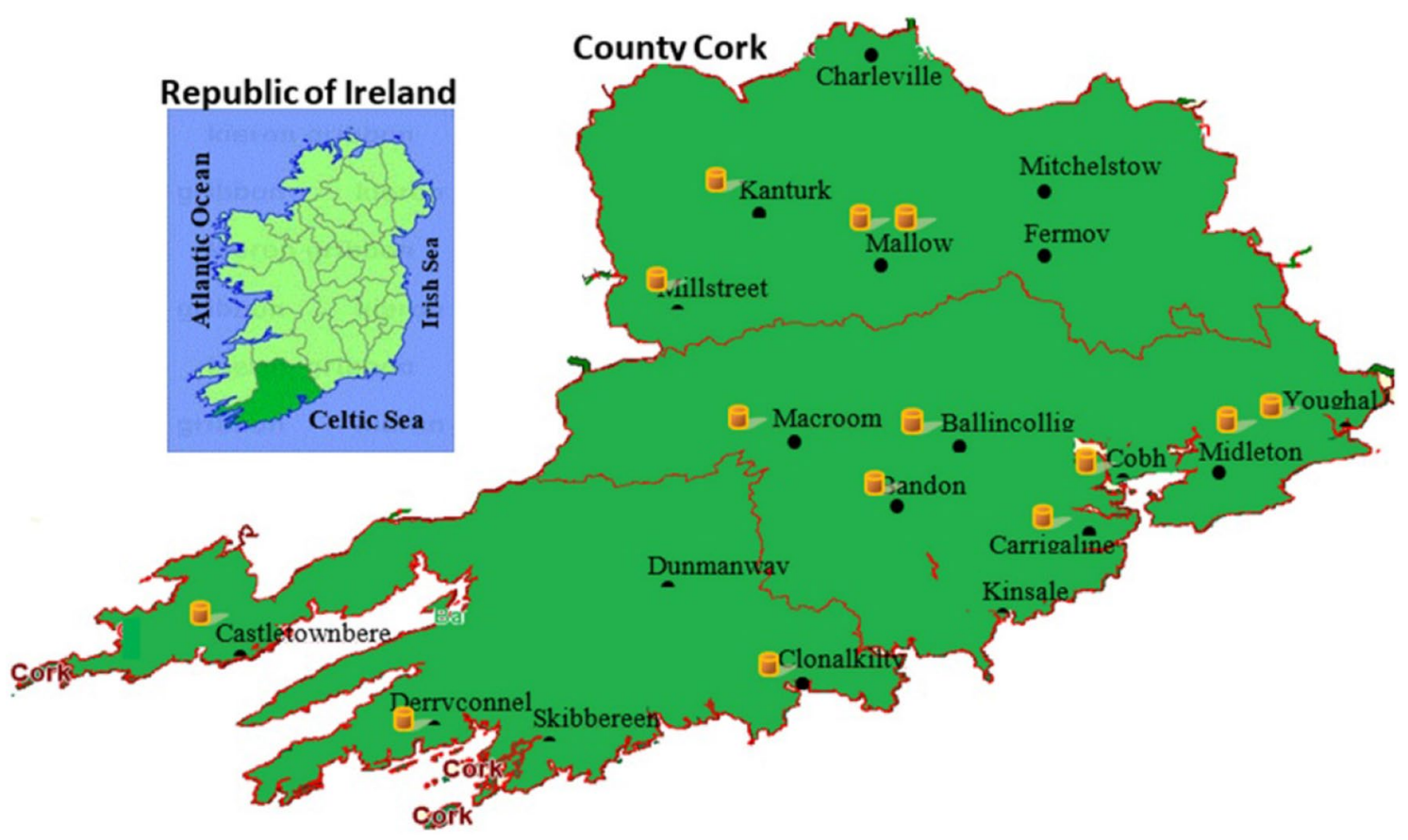

Fig. 4 Public and private civic amenity sites are marked (- ) within County Cork; map of Ireland (inset). [Environ. map viewer, Local Authority] 


\section{Waste collectors}

In County Cork there are 11 private collectors that are collecting kerb side waste at the moment, and six of them sent out promotional materials to the customers on how to segregate food waste and are also collecting food waste in a regular basis. Others are in the process of organizing their route for food waste collection. Waste companies are dealing directly with their customers-both private houses and commercial premises. To facilitate the achievements set out in European Union (Household Food Waste and Bio-Waste) Regulations 2013, Waste Management (Food Waste) Regulations 2009, waste companies mentioned above produce and distribute advertising materials about new food waste bin system to inform both householders and commercial premises in relation to the time frame for the roll out of the service and educate them on using the brown bin properly to avoid contamination. Collectors will have to adhere to improved standards of service, incentivize households and business owners to segregate food waste and be much clearer about their charging structures. Local authorities must organize regular meetings and monitor the activity of waste collectors. Keeping formal and proactive relationships with the waste collectors is crucial on success of this scheme. An estimate of organic waste collected has been reported by EPA in 2013 (Table 4). However, it is expected that food waste collection would increase significantly in coming years in Cork due to this awareness programme.

\section{Public awareness}

Public awareness is initiated by the Cork County local authority through brown bin advisers and through the Environmental Awareness Section. Brown bin advisers met both people in commercial premises, and households through door to door visits, organised six seminars in different locations under the banner such as 'Stop Food Waste', 'What's in your Bin' in collaboration with Environmental Awareness Section. In some cases, assistance has been provided by respective tidy town committees, and local grocery shops such as 'Supervalu' (chain super market in Ireland) to

Table 4 Estimated Organic (Food/Garden) Waste Component of Collected Household Waste-2013

\begin{tabular}{lll}
\hline Area & \multicolumn{2}{l}{ Kerbside collections (in tonnes) } \\
\cline { 2 - 3 } & $\begin{array}{l}\text { Mixed/residual collection } \\
\text { (black bins/bags) }\end{array}$ & $\begin{array}{l}\text { Organics col- } \\
\text { lection (brown } \\
\text { bins) }\end{array}$ \\
\hline Cork County & 54,282 & 234 \\
Southern Region & 240,404 & 16,593 \\
National sub-total & 737,782 & 83,389 \\
\hline
\end{tabular}

conduct the awareness campaign. Cork County Council also sent the message to the public through local radio stations, posters, newsletters, newspaper adverts. It has been found that methods where residents are contacted and informed individually are ominously more effective than information delivered using more traditional approach (such as leaflets only, media, etc). Similar trend also has been found by another study conducted by Evison and Read (2001). However, we have found that a common ground is created first by promoting the message through media, leaflets and posters (entrance of every town), followed by door to door visit- this ensured maximum efficiency, compared to any other method alone (Ghani et al. 2013). Grodzinska et al. (2006) suggested that public lack of knowledge was a serious obstacle to the fruitful execution of food waste recycling. It is found to be crucial for the residents to be able to understand and acknowledge the waste problem in their locality, before they feel responsible for the waste they produce or feel obliged to join in any schemes being provided. Knowledge about the availability of recycling programmes and facilities is necessary for effective participation of the people in food waste recycling (Siddique et al. 2010). That is why the implementation of the scheme was accompanied by awareness programme. Siddique also suggested that the effectiveness of the food waste recycling scheme relied upon enriched understanding and higher involvement by the people. Greater information and education programmes and increasing the accessibility of recycling facilities are the best means of promoting positive attitude to recycling, and help to remove barriers preventing residents from food waste recycling. However, public awareness programmes should not be a one off and must be continued after the initial implementation (Perrin and Barton 2001). Since cost is one of the important factors in taking the brown bin on board, particularly for the commercial premises, it is important to explain by providing real-life examples on cost effectiveness of using food waste or brown bin. In this work, a case study has been developed based on a small cafeteria located within Ballincollig in County Cork (Table 5). With the participation of the brown bin scheme a small-scale cafeteria can save around $€ 576$ in a year. Providing this case study to the similar commercial premises was found to be very effective in encouraging participation in the source segregation of food waste.

Small community garden compost sites are another form of solution to recycle food waste efficiently. Encouragement from Local Authorities for such development can create positive attitude within the community on food waste recycling. On behalf of Local Authority, brown bin advisers visited a number of such places, where the owners of commercial premises are happy to participate (Supplementary Fig. S3a-e). It would be more realistic to have such sites, which would be not as big as commercial or farm sites, and 
Table 5 Case study on cost status within a small cafeteria before and after using brown bin

\begin{tabular}{|c|c|c|c|c|c|c|c|c|}
\hline \multirow[t]{2}{*}{ Bin status } & \multicolumn{4}{|c|}{ Before brown bin } & \multicolumn{4}{|c|}{ After brown bin } \\
\hline & $\begin{array}{l}\text { Collection } \\
\text { frequency } \\
\text { (month) }\end{array}$ & Vol. of bin (1) & $\begin{array}{l}\text { Cost/col- } \\
\text { lection } \\
(€)\end{array}$ & Total cost $(€)$ & $\begin{array}{l}\text { Collection } \\
\text { frequency } \\
\text { (month) }\end{array}$ & Vol. of bin (1) & $\begin{array}{l}\text { Cost/col- } \\
\text { lection } \\
(€)\end{array}$ & Total cost $(€)$ \\
\hline General waste & 4 & 240 & 28 & 1344 & 1 & 240 & 28 & 336 \\
\hline Recycle waste ${ }^{\mathrm{a}}$ & 4 & 240 & 6 & 288 & 4 & 240 & 6 & 288 \\
\hline Food waste & NA & NA & NA & 0 & 4 & 120 & 9 & 432 \\
\hline Total cost/year $(€)$ & 1632 & & & & 1056 & & & \\
\hline $\begin{array}{l}\text { Cost saving/year (due } \\
\text { to using brown bin) } \\
(€)\end{array}$ & & & & & 576 & & & \\
\hline
\end{tabular}

${ }^{a}$ Recycle waste: paper, card board, dried plastics, tins, etc

also not as small as backyard compositing sites. However, few complaints are common, while retaining organic waste for reuse in the community gardens or small urban farm setting, such as smell, attracting pests, smelly pools of stagnant water due to the poor drainage during the compost. However, there are a number of steps a community garden or urban farm can take to reduce compositing problems: (1) composting process needs to be understood appropriately, (2) mixing materials appropriately to remove odour (Malakahmad et al. 2017), or adding odour-removing materials with the compost; (3) in addition to planning and selecting appropriate composting sites, environmental control measures need to be taken, which should include drainage system, along with other infrastructures, (4) effecting right management practices, (5) educating the locals on the benefit of having a compositing site within the neighbourhood; i.e. enrich the soil with organic material and microorganisms (Kuppusamy et al. 2017).

\section{Challenges in food waste recycling}

Based on the environmental model Source/Pathway/Receptor, challenges in relation to food waste recycling in Ireland starts from the food waste producer (Source), to waste collectors (Pathway), to destination of waste (Receptor). Challenges that are associated with the commercial premises are (1) lack of national awareness campaign, (2) quantity of commercial premises involved to be educated and lack of resources to educate commercial premises, (3) unauthorised usage of food waste, e.g. food for animals, (4) regulatory requirements for composting, (5) space issue for bins, (6) suitable collection times to overcome odour/vermin/volume issues. Moreover, continuous monitoring on the status of brown bin is also crucial, as it is natural that people are opening new premises, or closing the old one, or changing the ownership. In every case, it is important to do a followup from the local authority, so those particular premises update their food waste recycling status. A pilot study has been conducted in this study (Table 6), where brown bin advisers have visited in 2-year gap three towns. After visiting in 2014, good retention of brown bin has been found within the premises that have participated in the scheme in 2012; however, total number of commercial premises have been changed to more than double for both Ballincollig and Mallow towns, which is the effect of economic cycle of respective towns. Therefore, it is important for the local authority keep up to date on the status of new or old premises within particular region.

In the households, the challenges that are involved in Ireland at this moment are (1) lack of National awareness campaign, (2) quantity of households involved to be educated and lack of resources to educate households, (3) more usage of compost bins required, (4) mixing of non-food items with the food waste. A mixing of plastics or other non-food items
Table 6 Brown bin status in years 2012 and 2014

\begin{tabular}{|c|c|c|c|c|c|c|}
\hline \multirow[t]{3}{*}{ Towns } & \multicolumn{3}{|l|}{2012} & \multicolumn{3}{|l|}{2014} \\
\hline & \multirow[t]{2}{*}{ Total premises } & \multicolumn{2}{|c|}{ Brown bin $(\%)$} & \multirow[t]{2}{*}{ Total premises } & \multicolumn{2}{|c|}{ Brown bin $(\%)$} \\
\hline & & Yes & No & & Yes & No \\
\hline Ballincollig & 20 & 60 & 40 & 41 & 54 & 46 \\
\hline Mallow & 20 & 70 & 30 & 49 & 43 & 57 \\
\hline Millstreet & 15 & 73 & 27 & 19 & 42 & 581 \\
\hline
\end{tabular}


(Supplementary Fig. S4) in the food waste bin slows down the composting process in overall. From Supplementary Fig. $\mathrm{S} 4 \mathrm{~b}$ we can see that within 3 months all the food waste converted to fine grade compost. On the other hand, due to the presence of plastics and other non-food items, composting process gets slow. Even after 9 months, there were no significant changes in the waste (Supplementary Fig. S4a). There are also challenges from the waste collector's side, such as resistance to the introduction of food waste bins-often paying lip service and "offering" instead of "arranging" segregated food waste collection. Pictures of brown bin with and without compostable bags in Cork County are shown in Supplementary Fig. S5. Challenges that are involved with appropriate facilities, where people can take food waste, are (1) lack of awareness on home composting, (2) lack of authorised facilities, e.g. civic amenity sites/transfer stations/EPA sites accepting segregated food waste, (3) more enforcement of checking waste loads to ensure food waste is not included in general waste stream from areas where food waste regulations apply. In addition, when the new regulatory regime comes into effect, such as pay by weight or any other regulation is introduced into the community, it should be evident to everyone that this is beneficial both in environmental and financial terms (i.e. landfill levy will not be required for segregated food waste-it will only apply to waste going to landfills, etc.).

\section{Conclusions}

Successful engagement of the public to participate effectively in the food waste recycling scheme is of major concern to the local authorities. Analysis of responses from the survey from the local authority in 22 towns for the commercial premises, five towns for the households, along with local civic amenity sites and waste collectors that are working within County Cork indicates that an integrated strategy is crucial to roll out brown bin within a community. This strategy should involve a dedicated team from the local authority who continue to visit and monitor the public and co-ordinate the activities of local authorities, waste collectors, civic amenity sites and public to implement the food waste regulations. In addition to organising appropriate infrastructure for recycling of food waste, or in other words improving the convenience for the households and commercial premises on source segregation of food waste, continuous awareness raising through education, leaflets and local and national media is crucial. It is anticipated that neighbour pressure and fines for non-compliance will result in increased roll out of food waste recovery. Cost saving case studies relevant with the type of commercial premises or households found to be effective for the food producers in participating food waste recycle scheme. The role of local authorities should include facilitating the development of appropriate facilities such as composting, anaerobic digestion etc within communities and to encourage communities to take ownership of these facilities and reuse the resultant material within the local area. Moreover, when they see the direct implementation and output of their food waste; that will increase the food waste recycling and make the overall process cost effective in the long run.

Acknowledgements Thanks to Dr. Mary Stack, Environment Awareness Section, and Ms. Sharon Corcoran, Environment Directorate in Cork County Council; Mr. Percy Foster from Cre-Composting \& Anaerobic Digestion Association of Ireland and European Compost Network; and EPA, Ireland for their fruitful co-operation during this study. Also Cork County Council for funding this research.

Open Access This article is distributed under the terms of the Creative Commons Attribution 4.0 International License (http://creativeco mmons.org/licenses/by/4.0/), which permits unrestricted use, distribution, and reproduction in any medium, provided you give appropriate credit to the original author(s) and the source, provide a link to the Creative Commons license, and indicate if changes were made.

\section{References}

Austin J, Hatfield BD, Grindle AC, Bailey J (2003) Increasing recycling in office environments: the effects of specific, informative cues. J Appl Behav Anal 26:247-253. https://doi.org/10.1901/ jaba.1993.26-247

Berglund C (2006) The assessment of households' recycling costs; the role of personal motives. Ecolog Econom 56:560-569. https://doi. org/10.1016/j.ecolecon.2005.03.005

Bernstad A (2014) Household food waste separation behavior and the importance of convenience. Waste Manag 34:1317-1323. https:// doi.org/10.1016/j.wasman.2014.03.013

Dietz T, Stern PC, Guagno GA (1998) Social structural and social psychological bases of environmental concern. Environ Behav 30:450-471. https://doi.org/10.1177/001391659803000402

Evison T, Read AD (2001) Local authority recycling and wasteawareness publicity/promotion. Res Conserv Recyc 32:275-291. https://doi.org/10.1016/S0921-3449(01)00066-0

Ghani WA, Rusli IF, Biak DRA, Idris A (2013) An application of the theory of planned behaviour to study the influencing factors of participation in source separation of food waste. Waste Manag 33:1276-1281. https://doi.org/10.1016/j.wasman.2012.09.019

Grodzinska JM, Tomal P, Tarabula FM, Nieszporek K, Read AD (2006) Effects of an educational campaign on pubic environmental attitudes and behavior in Poland. Res Conserv Recyc 46:182-197. https://doi.org/10.1016/j.resconrec.2005.06.010

Hopper JR, Nielsen JM (1991) Recycling as altruistic behaviour: normative and behavioural strategies to expand participation in community recycling program. Environ Behav 23:195-220. https:// doi.org/10.1177/0013916591232004

Kosseva MR (2009) Processing of food wastes. Adv Food Nutr Res 58:57-136. https://doi.org/10.1016/S1043-4526(09)58003-5

Kuppusamy S, Venkateswarlu K, Megharaj M (2017) Evaluation of nineteen food waste for essential and toxic elements. Int J Recycl Org Waste Agric 6:367-373. https://doi.org/10.1007/s4009 3-017-0178-2

Malakahmad A, Idrus BN, Abualqumboz SM, Yavari S, Kutty MRS (2017) In-vessel co-compositing of yard waste and food waste: an 
approach for sustainable waste management in Cameron Highlands, Malaysia. Int J Recycl Org Waste Agric 6:149-157. https ://doi.org/10.1007/s40093-017-0163-9

Moh YC, Manaf LA (2014) Overview of household solid waste recycling policy status and challenges in Malaysia. Res Conserv Recyc 82:50-61. https://doi.org/10.1016/j.resconrec.2013.11.004

Perrin D, Barton J (2001) Issues associated with transforming household attitudes and opinions into materials recovery: a review of two kerbside recycling schemes. Res Conserv Recyc 33:61-74. https://doi.org/10.1016/S0921-3449(01)00075-1

Salemdeeb R, Dalna BM, Reynolds C, Tabbaa AA (2018) An environmental evaluation of food waste downstream management options: a hybrid LCA approach. Int J Recycl Org Waste Agric 7:217-229

Siddique FS, Joshi VS, Lupi F (2010) Factors influencing the rate of recycling: an analysis of Minnesota counties. Res Conserv Recyc 54:242-249. https://doi.org/10.1016/j.resconrec.2009.08.006

Spaccarelli S, Zolik E, Jason LA (1989) Effects of verbal prompting and block characteristics on participation in curbside newspaper recycling. J Environm Sys 19:45-57. https://doi.org/10.2190/ FXPM-UHC7-GXY6-JMJE
Sterner H, Bartelings T (1999) Household waste management in a Swedish municipality: determinants of waste disposal, recycling and composting. Environ Resour Econ 13:473-491. https://doi. org/10.1023/A:1008214417099

Vicente P, Reis E (2008) Factors influencing households' participation in recycling. Waste Manage Res 26:140-146. https://doi. org/10.1177/0734242X07077371

Widegren Ö (1998) The new environmental paradigm and personal norms. Environ Behav 31:75-100. https://doi.org/10.1177/00139 16598301004

Williams ID, Taylor C (2004) Maximising household waste recycling at civic amenity sites in Lancashire, England. Waste Manag 24:861874. https://doi.org/10.1016/j.wasman.2004.02.002

Publisher's Note Springer Nature remains neutral with regard to jurisdictional claims in published maps and institutional affiliations. 